\title{
MEMAKNAI KEMARAHAN ALLAH DARI SUDUT PANDANG TEOLOGI PENTAKOSTA DI ERA POST MODERN
}

\author{
Kosma Manurung \\ Program Studi Magister Teologi Sekolah Tinggi Teologi Intheos Surakarta \\ kosmamanurung@sttintheos.ac.id
}

\begin{abstract}
This article intends to give meaning to God's anger in the light of Pentecostal theology. The methodology used is text analysis and literature review. There are four examples of God's anger that were studied, namely God's anger towards Adam and Eve, God's anger towards the Israelites, the anger of the Lord Jesus towards the disciples, and the anger of the Lord Jesus towards the merchants in the Temple. The research results show that Allah is never angry for no apparent reason, and there is an impact of every anger of Allah. The causes of God's anger are disobedience, replacing God with other gods, injustice, and trading services. The impact of God's anger is separation from God, loss of the divine community, bringing God's judgment, and death.
\end{abstract}

Keywords: God is angry; the reasons God is angry; the impacts of God's anger; Pentacostal perspective; Pentacostal theology

Abstrak. Artikel ini bermaksud memberi pemaknaan terhadap kemarahan Allah dalam sudut pandang teologi Pentakosta. Metodologi yang digunakan yaitu analisis teks dan kajian literatur. Ada empat contoh kemarahan Allah yang diteliti yaitu kemarahan Allah kepada Adam dan Hawa, kemarahan Allah kepada bangsa Israel, kemarahan Tuhan Yesus kepada para murid, dan kemarahan Tuhan Yesus kepada para pedagang di Bait Allah. Hasil penelitian menunjukkan bahwa Allah tidak pernah marah tanpa alasan yang jelas dan ada dampak dari setiap kemarahan Allah. Penyebab kemarahan Allah adalah ketidaktaatan, menggantikan Allah dengan ilah lain, ketidakadilan, dan memperjualbelikan pelayanan. Adapun dampak kemarahan Allah adalah keterpisahan dengan Allah, kehilangan komunitas ilahi, mendatangkan penghukuman Allah, dan kematian.

Kata Kunci: Allah marah; alasan Allah marah; dampak kemarahan Allah; perspektif Pentakosta; teologi Pentakosta

Tuhan menciptakan manusia dengan menyertakan emosi di dalamnya dan jika dikaji dengan mendalam terkait emosi ini maka akan tergambar dua jenis emosi manusia yaitu yang bersifat positif dan negatif (Hayati \& Indra, 2018). Emosi yang bersifat positif ini contohnya senang, sayang, gembira, bahagia, kagum, tertawa. Sedangkan kecewa, sedih, marah, sakit hati adalah contoh emosi negatif dari manusia. Marah adalah 
aktivitas negatif bersifat menghancurkan yang kalau tidak ditangani dengan benar akan melahirkan tindakan-tindakan jahat yang merugikan bukan saja pada si pribadi yang marah tapi orang-orang yang menjadi obyek dari kemarahan itu. (Ekawati, 2018). Semenjak kejatuhan manusia, dosa telah masuk amat dalam dan menyebar begitu rupa dikehidupan umat manusia sehingga merusak banyak hal baik yang Tuhan ciptakan, termasuk juga merusak relasi serta menghancurkan komunikasi antar manusia tak terkecuali antar saudara dan orang tersayang yang semestinya dijaga dan dirawat dengan penuh kasih sayang. (Pono, 2018).

Alkitab ditulis dalam bahasa manusia untuk dipahami oleh manusia secara khusus oleh orang-orang yang hatinya telah disentuh oleh anugerah kemurahan Tuhan juga banyak membicarakan tentang topik marah. (K. Manurung, 2020b). Anak-anak Yakub menjadi marah karena Sikhem telah memperkosa Dina saudari mereka (Kej. 34). Daud marah terhadap Nabal dan memutuskan untuk mendatangkan celaka atas Nabal dan seisi rumahnya andai Abigail istri Nabal waktu itu tidak menenangkan hati Daud maka sudah pasti seluruh isi rumah nabal dihabisi oleh Daud (1 Sam 25). Ada juga cerita tentang kemarahan Raja Uzia karena ditegur oleh imam Azarya ketika dia membakar ukupan (2 Taw. 26). Elihu juga marah kepada Ayub dan ketiga sahabatnya (Ayb. 32). Perjanjian Baru ada Herodes Marah (Mat. 2). Gambaran ini ingin memperlihatkan bahwa kalau tidak ditangani dengan benar, ada hal buruk yang berupa rusaknya 
kualitas hidup yang amarah bawa dalam kehidupan seseorang. (Gamayanti \& Hidayat, 2019).

Pandangan Pentakosta meyakini benar bahwa Alkitab tidak mungkin salah dan apa yang Alkitab katakan adalah kebenaran mutlak yang harus diyakini sepenuhnya termasuk juga yang isinya terkait dengan kemarahan Allah. (Sutoyo, 2018). Allah marah terhadap Adam dan Hawa dan mengusir mereka dari Taman Eden karena lebih mendengarkan suara si jahat dari pada taat pada apa yang sudah Tuhan katakan untuk tidak memakan buah pohon pengetahuan yang baik dan yang jahat itu (Kej. 3). Allah juga marah dan ingin membinasakan bangsa Israel ketika mereka membuat anak lembu emas sehingga Musa harus melunakkan hati Tuhan untuk memohon pengampunan Tuhan atas bangsa Israel (Kel. 32).

Di kemudian hari Perjanjian Baru juga menulis tentang Tuhan Yesus yang adalah Allah dalam rupa manusia itu mengajarkan juga topik tentang marah (Mat. 5) bahkan Tuhan Yesus juga menunjukan kemarahan-Nya kepada para pedagang yang mengotori Bait Suci (Luk. 19). Dia juga menjadi marah ketika murid-murid-Nya menghalang-halangi anak-anak untuk datang pada-Nya (Mark. 10).

Dari paparan di atas nampak bahwa Allah bisa marah dan kemarahan tersebut memiliki dasar dan tujuan tertentu. Hal yang menarik untuk diteliti adalah: mengapa Allah marah dan apa dampaknya bila Allah marah? Penelitian ini bermanfaat bagi kehidupan umat percaya di masa 
kini dalam membangun kehidupan spiritualitasnya yang berkenan di hadapan Allah.

Untuk menggali penyebab dan dampak kemarahan Allah tersebut penulis akan menganalisis empat contoh dalam Alkitab yaitu: 1) kemarahan Allah kepada Adam dan Hawa; 2) kemarahan Allah kepada bangsa Israel dalam Keluaran 32; 3) kemarahan Tuhan Yesus kepada para murid dalam Markus 10; dan 4) kemarahan Tuhan Yesus kepada para pedagang di Bait Suci dalam Lukas 19.

\section{METODE}

Metodologi yang digunakan dalam penelitian ini adalah kualitatif dengan pendekatan analisis teks dan kajian Literatur. Analisis teks adalah analisis terhadap teks Alkitab dengan memperhatikan konteks penulisan waktu ini. (Soesilo, 2018). Kajian literatur merupakan kajian dengan menggunakan sumber kepustakaan berupa buku, artikel jurnal, dan terbitan lainnya yang terkait dengan penelitian yang sedang dilakukan (Marzali, 2017). Dengan kata lain, kajian literatur ini penekanannya pada sumber tertulis (Subekti et al., 2017). Adapun sudut pandang yang digunakan adalah sudut pandang teologi Pentakosta.

\section{HASIL}

\section{Penyebab Kemarahan Allah}

\section{Allah marah terhadap ketidaktaatan umat-Nya}


Alkitab mengambarkan ketidaktaatan identik dengan pemberontakan. Ketika Adam dan Hawa tidak taat pada perintah Allah untuk tidak memakan buah pengetahuan yang baik dan yang jahat, Allah melihat hal ini sebagai pemberontakan (Kej. 3). Begitu juga ketika Saul tidak taat pada apa yang Allah perintahkan melalui nabi Samuel, Allah melihat ketidaktaatan Saul sebagai pemberontakan terhadap perintah Allah dan Allah marah serta menghukum Saul (1 Sam. 15).

\section{Allah marah ketika umat-Nya menggantikan diri-Nya dengan ilah lain}

Allah begitu marah ketika orang Israel membuat lembu emas sebagai sesembahan (kel. 32). Dalam kemarahan-Nya Allah bahkan ingin membinasakan bangsa Israel. Namun Musa mencoba melunakan hati Allah sehingga Allah menyesal (Kel. 32:10-14).

\section{Allah marah ketika ketidakadilan terjadi}

Alkitab mengambarkan bahwa segala pekerjaan Allah itu adil, tidak ada kecurangan pada-Nya, sebab adil dan benar Dia (UI. 32:4; Maz. 116:5). Sebab itu Allah marah kepada orang yang melakukan ketidakadilan dan melakukan kelaliman (Yes. 19:1). Dalam Perjanjian Baru, Tuhan Yesus juga mengecam tindakan orang farisi yang menelan rumah para janda (Mat. 23:14).

\section{Allah marah ketika pelayanan diperjual belikan}

Melayani adalah anugerah sekaligus kehormatan yang Allah percayakan kepada kita. Perjanjian Lama menulis sebuah kisah tentang 
Bileam yang di minta oleh Balak untuk mengutuk bangsa Israel, Allah marah kepada Bileam bahkan mengutus malaikat-Nya berdiri di jalan dengan pedang terhunus ditangan sebagai lawan Bileam (Bil. 22: 22-32). Di kemudian hari terkait peristiwa Bileam ini, rasul Petrus menyimpulkan bahwa apa yang Bileam lakukan dan kematian yang menimpanya adalah sebagai upah perbuatan jahatnya (2 Pet. 2).

\section{Dampak Kemarahan Allah}

\section{Menjalani Kehidupan yang Terpisah dari Allah}

Akibat pertama dari kemarahan Allah adalah keterpisahan dari Allah. Kebersamaan Allah dengan Adam dan Hawa di taman Eden harus berakhir ketika mereka memberontak melalui ketidaktaatan mereka. Hal ini berarti mereka harus menjalani kehidupan yang terpisah dari Allah. Alkitab berkata Allah memerintahkan malaikat-Nya dengan pedang yang bernyala-nyala dan menyambar-nyambar, untuk menjaga jalan ke pohon kehidupan (Kej. 3:24).

\section{Keluar dari komunitas Ilahi}

Dampak lain dari kemarahan Allah yang Adam dan Hawa alami adalah keluar dari komunitas Ilahi. Alkitab mengambarkan bahwa selama di taman Eden, ada keharmonisan hubungan yang begitu indah antara Adam, Hawa, dan Allah. Mereka hidup dalam komunitas Ilahi yang begitu indah. Sayangnya, ketidaktaatan mereka akhirnya menyebabkan Allah marah dan mereka harus terusir dari komunitas llahi ini. 


\section{Hidup dalam penghukuman Allah}

Kemarahan Allah menyebabkan penghukuman Allah. Allah marah terhadap Ahab karena perbuatan jahatnya yang menggantikan Allah Israel dengan Baal dan Dewi Asyera (1 Rj. 16: 30-33), dan kemudian mengakibatkan orang Israel berpaling dari Allah. Di akhir dari hidupnya, nasib tragis menimpa Ahab, ia mati dalam peperangan dengan Arah, darahnya dijilati anjing di tempat perempuan sundal mandi (1 Rj. 22:3438).

\section{Kematian}

Kematian adalah dampak kemarahan Allah karena dosa pemberontakan manusia dalam hal ini Adam dan Hawa di taman Eden. Semenjak pemberontakan itu, kematian sudah menjadi bagian yang tidak terpisahkan dari kehidupan manusia. Upah dosa memang kematian (maut) namun orang percaya memiliki karunia Allah berupa hidup yang kekal didalam Kristus Yesus (Rm. 6: 23).

\section{PEMBAHASAN}

\section{Contoh-contoh Kemarahan Allah}

\section{Allah Marah kepada Adam dan Hawa}

Alkitab yang merupakan otoritas tertinggi tertulis yang mengatur iman dan perilaku orang percaya menyatakan bahwa Allah adalah pencipta segala sesuatu (K. Manurung, 2020a). Alkitab dari Kejadian sampai Wahyu menempatkan Allah sebagai pencipta. Hal ini merupakan 
titik sentral di mana orang percaya, tak terkecuali kaum Pentakosta, menaruh pemahaman, keyakinan, dan pengharapan. (Arrington, 2020).

Alkitab memberikan gambaran bahwa manusia adalah ciptaan Tuhan yang paling istimewa dibandingkan dengan ciptaan Tuhan lainnya (Arrington, 2020). Keistimewaan manusia adalah Allah menciptakan mereka segambar dan serupa dengan Dia. Demikian juga Allah memberikan tanggung jawab untuk memelihara segala ciptaan-Nya. Sayangnya manusia memberontak terhadap Allah dengan alasan yang sangat ironis yaitu ingin menjadi serupa dengan Allah. (Edward Schnittjer, 2015). Allah begitu marah akan tindakan manusia yang lebih mendengarkan kebohongan iblis dibandingkan tunduk dan taat pada perintah-Nya untuk tidak makan buah pengetahuan yang baik dan yang jahat (Kej. 3).

Allah bertindak dengan sangat keras kepada pemberontakan yang dilakukan oleh Adam dan Hawa. Allah mengutuk mereka. Adam harus bersusah payah dan berjerih lelah untuk mencari rezeki. Hawa akan merasakan susah payah saat mengandung dan kesakitan yang sangat saat melahirkan, akan birahi pada suami, dan suaminya akan berkuasa padanya. Pada awalnya Hawa adalah mitra yang setara (sepadan) dengan Adam namun akibat mendengarkan bujuk rayu si jahat Hawa akhirnya mengalami degradasi posisi menjadi yang "dikuasai" oleh Adam (Lasor et al., 2015). Tidak berhenti sampai di situ, Allah mengusir Adam dan Hawa dari Taman Eden. Kata mengusir di sini bisa juga dimaknai 
sebagai sebuah tindakan yang menyatakan memutuskan hubungan, tidak mau lagi berurusan, dan memutuskan untuk berpisah atau bercerai ( $\mathrm{K}$. Manurung, 2020a).

\section{Allah Marah kepada Bangsa Israel dalam Keluaran 32}

Keluaran 32 menulis kisah di mana Allah murka terhadap bangsa Israel sampai bermaksud membinasakan mereka. Kitab Keluaran menggambarkan bagaimana Allah telah berkenan melalui hamba-Nya Musa untuk membebaskan mereka dari perbudakan di Mesir. Setelah berhasil keluar dari Mesir, di tengah perjalanan Allah secara khusus menuliskan sepuluh perintah-Nya. Kesepuluh perintah ini memiliki kedudukan yang unik dan sangat istimewa, mengatur tentang ketetapanketetapan pokok hubungan baik dengan Allah dan sesama manusia serta dianggap pusat dan sumber tertinggi. (Sitopu, 2020). Allah memanggil Musa ke atas gunung untuk menerima kesepuluh perintah tersebut.

Penulis Keluaran 32 ini mengambarkan ketika Musa mengulur-ulur waktu untuk turun dari gunung, orang Israel berkumpul mengerumuni Harun yang pada intinya ingin dibuatkan allah yang nantinya akan berjalan didepan mereka. Kemudian karena desakan umat pada waktu itu akhirnya Harun menyerah dan menuruti keinginan mereka untuk membuat allah berbentuk anak lembu emas dan hal ini membuat bangsa Israel waktu itu bergembira-ria dalam pesta pora mereka terkait peristiwa ini sebagian besar penafsir memaknainya sebagai sebagai peristiwa liar, penuh mabuk-mabukan, dan seks. (Edward Schnittjer, 2015). Padahal pada saat 
yang sama, Musa yang sedang berada di atas gunung sedang menerima sepuluh perintah Allah yang langsung ditulis oleh tangan Allah sendiri (Wolf, 2017). Ada dua kondisi kerohanian yang begitu kontras yang sedang ditonjolkan oleh penulis kitab Keluaran dalam perikop ini dan di antara kekontrasan rohani tersebut penulis kitab Keluaran menyelipkan perspektif Allah terhadap situasi ini yaitu Allah marah. Perikop ini pun juga menjelaskan Musa yang ikut marah melihat perbuatan orang Israel waktu itu sehingga Musa menyuruh orang Israel meminum abu dari anak lembu mas yang Musa bakar dan menugaskan orang-orang Lewi untuk mengambil pedang mereka dan membunuh para pemberontak (Wolf, 2017).

\section{Tuhan Yesus Marah Kepada Para Murid dalam Markus 10}

Keempat kitab pertama dalam Perjanjian Baru biasanya disebut dengan Injil pada intinya berisikan tentang kehadiran, pelayanan, dan tindakan-tindakan Tuhan Yesus untuk menebus dan menyelamatkan umat manusia selama Dia mengambil rupa sebagai manusia (Setiawan, 2019). Dari informasi yang dicatat Injil ini peneliti menemukan satu peristiwa yang dicatat tentang oleh penulis Markus terkait kemarahan Tuhan Yesus, kali ini yang menjadi sasaran kemarahan Tuhan adalah para murid-Nya (Mark. 10).

Mengapa Tuhan Yesus sampai marah kepada para murid-Nya waktu itu? Menurut penulis Markus, hal itu dikarenakan para murid menghalangi anak-anak untuk datang kepada Yesus. Seberapa 
pentingkah anak-anak di mana Tuhan Yesus sehingga Tuhan marah terhadap murid-murid-Nya? Anak-anak sering menjadi korban pelecehan bahkan korban kekerasan entah itu pelecehan/ kekerasan verbal, fisik bahkan kekerasan sexual. Anak-anak juga mewakili kaum yang tidak berdaya, butuh perlindungan, butuh bimbingan, dan butuh diayomi. Tuhan marah kepada para murid-Nya karena bukannya ambil bagian menjadi teladan dalam memperlakukan anak-anak, para murid justru ambil bagian dalam melakukan tindakan yang melukai perasaan dan kejiwaan anakanak ini. (Hutabarat, 2019).

Karakter dan kepribadian Kristus adalah keagungan-Nya (Siburian, 2018). Bagaimana Tuhan marah ketika ada anak-anak yang tidak diperlakukan benar merupakan bukti nyata keagungan dari karakter Tuhan. Sangat berbeda dengan masa kini di mana banyak orang baik akan diam saja nyaris tidak berbuat apa-apa untuk bertindak membela dan mengayomi yang butuh perlindungan, atau yang terpinggirkan dengan berbagai dalih. Melalui topik kemarahan ini penulis kitab Markus ingin menonjolkan gambaran tentang Yesus yang adalah contoh sempurna bagi para murid waktu itu bagaimana seharusnya berperilaku dalam kehidupan bermasyarakat, serta merespon dengan tindakan kasih yang lahir dari tanggung jawab yang benar untuk mengasihi dan melayani sesama tanpa pandang bulu (Gea, 2018), Apa yang para murid pelajari hari itu yaitu belajar tentang keteladanan karakter Tuhan yang begitu mulia dan penuh belas kasihan tentang bagaimana memperlakukan anak-anak biarlah juga 
menjadi inspirasi serta mengisi setiap tindakan orang percaya masa kini (Katarina \& Siswanto, 2018).

\section{Yesus Marah Kepada Para Pedagang di Bait Suci dalam Lukas 19}

Injil Lukas secara keseluruhan bisa disimpulkan sebagai Injil yang berisikan narasi teologis yang ditulis oleh satu-satunya orang bukan Yahudi yang menulis Alkitab yang orang percaya miliki saat ini. (Ambesa, 2020). Kemarahan Tuhan Yesus di Bait Suci adalah contoh lain yang Alkitab catat tentang kemarahan Allah dan kali ini yang menjadi objek kemarahan Allah adalah para pendagang yang berjualan di Bait Allah (Luk. 19). Penulis kitab Lukas mengambarkan bagaimana Tuhan Yesus begitu marah dan mengusir para pedagang yang berjualan dan menyebut mereka penyamun. Penyamun adalah orang yang merampas atau merampok hak orang lain dan mengakibatkan penderitaan pada orang lain. (Rusmiati et al., 2018). Kata mengusir di sini bisa dimaknai dengan menyeret keluar karena dianggap melakukan perbuatan yang jahat. Artinya dalam pandangan Tuhan Yesus waktu itu tindakan yang para pedagang ini lakukan waktu itu bukanlah perbuatan yang layak untuk dipuji atau diteladani melainkan perbuatan yang seharusnya dihindari dan tidak pernah dilakukan.

Tuhan Yesus dalam kemarahan-Nya menyatakan bahwa Bait Allah adalah rumah-Nya dan mengingatkan para pendengar waktu itu bahwa Bait Allah seharusnya menjadi rumah doa bukan rumah bagi sarang penyamun. Hal lain dari kemarahan Tuhan Yesus yang coba ditonjolkan 
Lukas dalam konteks perikop ini adalah dengan begitu piawai dalam tulisannya, Lukas membangun narasi teologinya memaparkan Ketuhanan Kristus (F. S. Manurung, 2018). Setiap tindakan yang dilakukan oleh Tuhan Yesus bukanlah tindakan yang digerakan oleh emosi melainkan hasil dari pemikiran yang matang. Ketika Tuhan marah Dia tidak bertindak sembrono namun ada pesan kuat yang ingin Tuhan ajarkan kepada setiap orang yang mendengar waktu itu dan kepada kita saat ini yaitu jangan pernah berikan kesempatan uang menguasai dan membutakan kita sehingga menjadi penghalang untuk menyenangkan Tuhan. (Lilo, 2019).

\section{Kajian Kekinian Teologi Pentakosta tentang Kemarahan Allah}

\section{Penyebab Kemarahan Allah}

Ketidaktaatan menyebabkan Allah marah. (K. Manurung, 2020a). Ketika Adam dan Hawa tidak taat Allah marah, ketika bangsa Israel tidak taat Allah marah, ketidaktaatan Saul menyebabkan Allah marah, dan banyak contoh lainnya bagaimana Allah marah karena ketidak taatan orang percaya. Keluaran 19 mengambarkan bangsa Israel sebagai harta kesayangan Allah diantara segala bangsa, menjadi kerajaan iman dan bangsa yang Kudus (Lasor et al., 2015). Namun Alkitab juga mencatat berkali-kali bangsa Israel menyakiti hati Tuhan dan membuat Tuhan marah. Apakah dalam kemarahan Allah tidak ada kasih-Nya? Teologi Pentakosta meyakini benar bahwa Allah adalah Allah yang maha kasih dan salib adalah puncak dari pernyataan kasih Allah (Zaluchu, 2017). Untuk menaati Allah, kebenaran Allah haruslah harus bisa 
diimplementasikan dalam kehidupan praktis orang percaya dan ini berarti kebenaran Alkitab harus masuk ke seluruh lini kehidupan orang percaya. (Stevanus, 2018).

Menggantikan Allah dengan ilah lain juga merupakan tindakan yang membuat Allah marah. Perjanjian Lama memberikan gambaran bahwa umat Israel tidak boleh memberikan ruang bagi ilah lain apalagi menempatkan ilah itu setara atau melampaui Allah. (Lumingkewas, 2019). Kajian terhadap Keluaran 32 tentang bagaimana Allah murka ketika bangsa Israel membuat ilah anak lembu emas adalah contoh yang sangat jelas mengenai sikap Allah yang marah ketika ada ilah lain yang berusaha disembah oleh bangsa Israel. Mengacu pada yang Alkitab gambarkan bagaimana Allah melalui kasih-Nya membangun hubungan dengan umat Israel, tidak heran jika Allah sangat benci dan marah ketika umat pilihan mulai membicarakan apalagi mulai memuja ilah lain, tentu saja hal ini sangat melukai hati Allah dan membuat la marah. (Wauran, 2015).

Hal lainnya yang membuat Allah marah adalah kerena ketidakadilan. Ketidakadilan selalu bersifat merusak, di manapun ketidakadilan itu ada maka akan disusul oleh kerusakan dan kekacauan. (Taftazani, 2017). Ketika di rumah ada perlakuan yang tidak adil atau pilih kasih maka akan ada anak yang merasa dinomor duakan, merasa kurang disayangi, dan akibat selanjutnya kalau tidak segera diatasi akan menimbulkan tindakan-tindakan yang mengganggu keharmonisan keluarga. Tentunya akibat ketidak adilan akan lebih fatal apabila ketidak 
adilan itu terkait dengan masyarakat yang lebih luas. Allah adalah Allah yang adil dan bertindak adil merupakan karakter Allah. (Mamahit, 2010). Kajian terhadap Markus 10 memperlihatkan bagaimana Tuhan Yesus bereaksi keras terhadap para murid yang tidak adil dalam memperlakukan anak-anak.

Allah marah ketika pelayanan diperjual belikan. Lukas 19 memperlihatkan bagaimana reaksi Tuhan Yesus bukan sekedar marah dan menyebut orang yang berjualan disekitar Bait Allah sebagai penyamun, melainkan juga Tuhan mengusir mereka. Tindakan mengusir disini bisa juga dipahami sebagai sebuah tindakan ketidaksukaan dari Tuhan terhadap apa yang waktu itu para pedagang lakukan di Bait Allah. Di kemudian hari Paulus memperingatkan orang percaya bahwa ada orang-orang yang sepertinya melayani Allah tetapi sebetulnya mereka sedang melayani perut mereka (Rm. 16). Orang yang melayani Allah seharusnya mengikuti teladan Kristus secara konsisten dalam hati dan pola pikir yang murni dan kudus, jangan hanya awal-awal pelayanan saja hatinya murni tetapi setelah mulai besar dan terkenal mulai dikuasai keinginan untuk menikmati kemapanan dalam segala mancam bentuknya, tak jarang bahkan melayani untuk tujuan mendapatkan materi. (Nelly \& Gultom, 2020).

\section{Dampak Kemaraham Allah}

Keterpisahan dari Allah adalah dampak pertama yang dialami oleh manusia ketika membangkitkan kemarahan hati Allah. (Hannas \& 
Rinawaty, 2019). Manusia tidak pernah dirancang oleh Allah untuk menjalani kehidupan yang terpisah dari Allah, ketika hal ini terjadi maka Alkitab menggambarkan bahwa hidup yang terpisah dari Allah yang dijalani manusia adalah kehidupan yang di dalamnya banyak masalah dan penderitaan. Adam dan Hawa adalah manusia pertama yang mengalami keterpisahan sebagai akibat dari kemarahan Allah. Yesus Kristus yang adalah Adam kedua pernah mengalami beberapa saat "keterpisahan" dari Allah, dan mengerti benar bagaimana cara memulihkan kembali hubungan manusia dengan Allah yang sudah rusak, serta menyelamatkan orang berdosa untuk mendapatkan kehidupan kekal melalui karya salib-Nya. (Wicaksono \& Anggono, 2019). Teologi Pentakosta berkeyakinan bahwa satu-satunya cara untuk memulihkan hubungan yang terpisah dari Allah ini adalah hanya melalui Tuhan Yesus (Zaluchu, 2017).

Alkitab berkali-kali memakai gambaran perkawinan ini untuk mengambarkan hubungan antara Allah dan umat-Nya maupun Kristus dan gereja-Nya. (Stanislaus, 2017). Tak bisa dipungkiri bahwa manusia butuh komunitas untuk tumbuh kembangnya. Komunitas yang baik berpengaruh besar untuk kesuksesan seseorang. Keluarga adalah komunitas terkecil dari suatu masyarakat yang terbentuk dari ikatan perkawinan yang sah antara seorang pria yang kemudian menjadi suami dan kepala keluarga dan seorang wanita. Dampak kemarahan Allah membuat manusia keluar dari komunitas ilahi. (Hannas \& Rinawaty, 2019). Hal ini terlihat jelas bagaimana melalui pemberontakan yang 
dilakukan oleh Adam dan Hawa mengakibatkan mereka harus kehilangan hak untuk tinggal di taman Eden yang merupakan tempat tinggal mereka selama ini.

Akibat lainnya yang akan terjadi ketika Allah marah adalah adanya penghukuman Allah. Ketidaktaatan, mengantikan Allah dengan ilah lain, memperjual belikan pelayanan, dan kegagalan memahami hati Tuhan membuat dosa berkuasa atas hidup seseorang, penghukuman Allah hanyalah masalah waktu saja terjadinya pada hidup orang tersebut (Wasiyona, 2019). Yang paling mengerikan adalah hukuman kekal yang menanti setiap manusia di akhir zaman. Allah menghukum bukan karena digerakan keinginan hati yang dipenuhi perasaan dendam yang begitu memuncak untuk bertindak melainkan keadilan Allah-lah yang menuntut Dia untuk melakukan penghukuman. (Marbun, 2020). Kaum pentakosta melihat bahwa kemiskinan, penderitaan, kesusahan disatu sisi memang akibat dari kemarahan Tuhan karena perbuatan manusia namun disisi lain sebaiknya dipahami sebagai sebuah kesempatan yang Tuhan ijinkan. (Ambesa, 2020). Kesempatan untuk bertobat, mendapatkan pengampunan dan anugarah Allah serta kembali pada Allah.

Kematian adalah dampak kemarahan Allah. Dalam Kejadian 3 Allah berfirman melarang manusia untuk memakan pohon pengetahuan yang baik dan jahan karena pada hari mereka memakannya mereka pasti akan mati. Adam dan Hawa tidak mentaati firman Allah dan mengulurkan tangan mereka untuk memakan buat pohon pengetahuan itu. Alkitab 
selanjutnya menulis bahwa dosa pemberontakan mereka adalah penyebabnya dan kematian adalah akibatnya. (EDWARD SCHNITTJER, 2015). Kaum Pentakosta mengimani bahwa kematian Kristus dikayu salib dan kebangkitan-Nya memberikan bukti sekaligus jaminan kepada orang percaya bahwa sengat maut sudah dipatahkan dan kematian tubuh jasmani kita hanya merupakan sebuah pintu untuk memasuki kekekalan bersama Tuhan Yesus. (Zega, 2020).

\section{KESIMPULAN}

Allah adalah Allah yang penuh kasih sekaligus juga Allah yang adil. Keadilan Allah menuntut Allah untuk bertindak. Alkitab mencatat bahwa kadang untuk menunjukan tindakan keadilan-Nya Allah Marah. Artikel ini membahas empat contoh kemarahan Allah yaitu Allah marah kepada Adam dan Hawa, Allah marah kepada bangsa Israel, Tuhan Yesus marah kepada para murid, dan Tuhan Yesus marah kepada para pedagang di Bait Allah. Berdasarkan hasil penelitian artikel ini penyebab kemarahan Allah karena ketidaktaatan, menggantikan Allah dengan ilah lain, ketidakadilan, dan memeperjual belikan pelayanan. Adapun dampak kemarahan Allah adalah keterpisahan dengan Allah, kehilangan komunitas ilahi, mendatangkan penghukuman Allah, dan kematian.

Kiranya hasil penelitian artikel ini bisa memperkaya khazanah keilmuan teologi secara khusus teologi Pentakosta. Artikel ini bisa digunakan sebagai bahan rujukan bagi para peneliti lain yang ingin menggali topik terkait kemarahan Allah atau terkait topik teologi 
Pentakosta lainnya. Harapan peneliti kedepannya akan ada banyak penelitian yang mengkaji topik tentang teologi Pentakosta sehingga ada lebih banyak lagi sumber acuan maupun bahan dengan standar akademik yang baik yang memperkaya teologi Pentakosta.

\section{DAFTAR PUSTAKA}

Ambesa, S. (2020). Penyakit Dan Kelaparan: Telaah Perkataan Yesus Dalam Lukas 21:11 Dan Relevansinya Bagi Gereja Di Masa Pandemi Covid-19. Diegesis: Jurnal Teologi, 5(2), 43-53. https://doi.org/10.46933/dgs.vol5i243-53

Arrington, F. L. (2020). Doktrin Kristen Perspektif Pentakosta. Andi Offset.

Edward Schnittjer, G. (2015). The Torah Story. Gandum Mas.

Ekawati, M. (2018). Kesantunan Semu Pada Tindak Tutur Ekspresif Marah Dalam Bahasa Indonesia. Adabiyyāt: Jurnal Bahasa dan Sastra, 1(1), 1-22. https://doi.org/10.14421/ajbs.2017.01101

Gamayanti, W., \& Hidayat, I. N. (2019). Marah Dan Kualitas Hidup Orang Yang Mengalami Psikosomatik. Jurnal Psikologi, 18(2), 177-186. https://doi.org/10.14710/jp.18.2.177-186

Gea, I. (2018). 5 (Lima) Nilai Budaya Kerja Kementrian Agama (Analisis dari Injil Sinoptis). KENOSIS: Jurnal Kajian Teologi, 2(1), 1-22. https://doi.org/10.37196/kenosis.v2i1.30

Hannas, H., \& Rinawaty, R. (2019). Apologetika Alkitabiah tentang Penciptaan Alam Semesta dan Manusia terhadap Kosmologi Fengshui sebagai Pendekatan dalam Pekabaran Injil. DUNAMIS: Jurnal Teologi dan Pendidikan Kristiani, 4(1), 55-74. https://doi.org/10.30648/dun.v4i1.206

Hayati, R., \& Indra, S. (2018). Hubungan Marah Dengan Perilaku Agresif Pada Remaja. Jurnal Edukasi: Jurnal Bimbingan Konseling, 4(1), 6774. https://doi.org/10.22373/je.v4i1.3523

Hutabarat, O. R. (2019). Mendidik Anak Berkarakter Kristen Mengatasi Kekerasan. Voice of Wesley: Jurnal IImiah Musik dan Agama, 1(2). https://doi.org/10.36972/jvow.v1i2.12

Katarina, K., \& Siswanto, K. (2018). Keteladanan Kepemimpinan Yesus Dan Implikasinya Bagi Kepemimpinan Gereja Pada Masa Kini. 
Evangelikal: Jurnal Teologi Injili dan Pembinaan Warga Jemaat, 2(2), 87-98. https://doi.org/10.46445/ejti.v2i2.102

Lasor, W. S., Hubbard, D. A., \& Bush, F. W. (2015). Pengantar Perjanjian Lama 1. BPK Gunung Mulia.

Lilo, D. D. (2019). Presuposisi dan Metode Yesus dalam Menyampaikan Pendapat: Sebuah Pedoman bagi Para Akademisi. BIA': Jurnal Teologi dan Pendidikan Kristen Kontekstual, 2(1), 121-138. https://doi.org/10.34307/b.v2i1.86

Lumingkewas, M. S. (2019). One God or One Lord? Deuteronomi and the Meaning of Monotheism. FIDEI: Jurnal Teologi Sistematika dan Praktika, 2(2), 388-410. https://doi.org/10.34081/fidei.v2i2.79

Mamahit, F. Y. (2010). Teologi dan Praksis Keadilan dalam Kitab Taurat. Veritas: Jurnal Teologi dan Pelayanan, 11(1), 1-21. https://doi.org/10.36421/veritas.v11i1.227

Manurung, F. S. (2018). Teologi Keramahan Allah: Sebuah Pembacaan Kristologi Lukas. Gema Teologika: Jurnal Teologi Kontekstual dan Filsafat Keilahian, 3(2), 185-206.

Manurung, K. (2020a). Taurat dan Nubuat Palsu: Kajian Sudut Pandang Taurat Terhadap Nubuat Palsu. Jurnal Teologi Berita Hidup, 2(2), 94109.

Manurung, K. (2020b). Ketubim dan Nubuat. Pengarah: Jurnal Teologi Kristen, 2(2), 129-140. https://doi.org/10.36270/pengarah.v2i2.24

Marbun, P. (2020). Konsep Dosa dalam Perjanjian Lama dan Hubungannya dengan Konsep Perjanjian. CARAKA: Jurnal Teologi Biblika dan Praktika, 1(1), 1-16. https://doi.org/10.46348/car.v1i1.9

Marzali, A.-. (2017). Menulis Kajian Literatur. ETNOSIA : Jurnal Etnografi Indonesia, 1(2), 27-36. https://doi.org/10.31947/etnosia.v1i2.1613

Nelly, \& Gultom, L. (2020). Menerapkan Keteladanan Yesus sebagai Guru berdasarkan Injil Lukas bagi Guru SMA Kristen Adhi Wiyata Jember. Paeda' - Jurnal Pendidikan Kristen, 1(1), 59-71.

Pono, M. R. (2018). Memahami Makna Relasi Dan Keberadaan Manusia Dalam Film "Her" Berdasarkan Perspektif Filsafat Fenomenologi Emmanuel Levinas. KENOSIS: Jurnal Kajian Teologi, 4(1), 39-56. https://doi.org/10.37196/kenosis.v4i1.50

Rusmiati, R., Syahrizal, S., \& Din, M. (2018). Konsep Pencurian Dalam Kitab Undang-Undang Hukum Pidana dan Hukum Pidana Islam. Syiah Kuala Law Journal, 1(1), 339-352. https://doi.org/10.24815/sklj.v1i1.12318 
Setiawan, D. E. (2019). Dampak Injil Bagi Transformasi Spiritual Dan Sosial. BIA': Jurnal Teologi dan Pendidikan Kristen Kontekstual, 2(1), 83-93. https://doi.org/10.34307/b.v2i1.78

Siburian, T. (2018). Perspektif Kristologis Mengenai'Yesus Guru Agung.' Jurnal Teologi STULOS, 16(2), 179-207.

Sitopu, E. (2020). Memahami Dan Memaknai Berbagai Peraturan, Ketetapan, dan Hukum Dalam Taurat. Jurnal Christian Humaniora, 4(1), 33-44. https://doi.org/10.46965/jch.v4i1.10

Soesilo, Y. (2018). Pentakostalisme dan Aksi Sosial: Analisis Struktural Kisah Para Rasul 2:41-47. DUNAMIS: Jurnal Teologi dan Pendidikan Kristiani, 2(2), 136-151. https://doi.org/10.30648/dun.v2i2.172

Stanislaus, S. (2017). Perkawinan Dalam Kitab Suci Perjanjian Lama. Logos Jurnal Publikasi, 14(2), 17-51.

Stevanus, K. (2018). Mengimplementasikan Pelayanan Yesus Dalam Konteks Misi Masa Kini Menurut Injil Sinoptik. FIDEI: Jurnal Teologi Sistematika dan Praktika, 1(2), 284-298. https://doi.org/10.34081/fidei.v1i2.21

Subekt, H., Taufiq, M., Susilo, H., Ibrohim, I., \& Suwono, H. (2017). Mengembangkan Literasi Informasi Melalui Belajar Berbasis Kehidupan Terintegrasi Stem Untuk Menyiapkan Calon Guru Sains Dalam Menghadapi Era Revolusi Industri 4.0: Revieu Literatur. Education and Human Development Journal, 3(1), 81-90. https://doi.org/10.33086/ehdj.v3i1.90

Sutoyo, D. (2018). Analisis Historis terhadap Teologi Gerakan Pentakostalisme. DUNAMIS: Jurnal Teologi dan Pendidikan Kristiani, 2(2), 167-196. https://doi.org/10.30648/dun.v2i2.171

Taftazani, B. M. (2017). Masalah Sosial dan Wirausaha Sosial. Share: Social Work Journal, 7(1), 90-108. https://doi.org/10.24198/ share.v7i1.13822

Wasiyona, N. (2019). Memahami Teologi Paulus tentang Dosa. SOTIRIA (Jurnal Teologi dan Pelayanan Kristiani), 2(2), 79-87.

Wauran, Q. C. (2015). Kajian Biblika Kecemburuan Allah Terhadap Penyembahan Berhala Berdasarkan Keluaran 20:4-6. Jurnal Jaffray, 13(2), 249-284. https://doi.org/10.25278/jj71.v13i2.180

Wicaksono, A.-, \& Anggono, D. (2019). Yesus, Hamba Allah Yang Menderita. FIDEl: Jurnal Teologi Sistematika dan Praktika, 2(1), 142158. https://doi.org/10.34081/fidei.v2i1.44

Wolf, H. (2017). Pengenalan Pentateukh. Gandum Mas. 
Zaluchu, S. (2017). Penderitaan Kristus Sebagai Wujud Solidaritas Allah Kepada Manusia. DUNAMIS: Jurnal Penelitian Teologi dan Pendidikan Kristiani, 2(1), 61-74. https://doi.org/10.30648/ dun.v2i1.129

Zega, S. (2020). Keberadaan Jiwa Orang Percaya Setelah Kematian Menurut 1 Tesalonika 4:14. ERESI Jurnal Teologi dan Pendidikan Kristiani, 1(1), 34-60. 